\title{
Availability and Plant Uptake of Biosolid-Borne Metals
}

\author{
Bon-Jun Koo, ${ }^{1,2}$ Andrew C. Chang, ${ }^{2}$ David E. Crowley, ${ }^{2}$ \\ Al L. Page, ${ }^{2}$ and Alexandria Taylor ${ }^{1}$ \\ ${ }^{1}$ Department of Natural and Mathematical Sciences, California Baptist University, Riverside, CA 92504-3297, USA \\ ${ }^{2}$ Department of Environmental Sciences, University of California, Riverside, CA 92521-0001, USA
}

Correspondence should be addressed to Bon-Jun Koo; bonjunkoo@calbaptist.edu

Received 12 July 2013; Revised 16 September 2013; Accepted 18 September 2013

Academic Editor: Rodrigo Studart Corrêa

Copyright (C) 2013 Bon-Jun Koo et al. This is an open access article distributed under the Creative Commons Attribution License, which permits unrestricted use, distribution, and reproduction in any medium, provided the original work is properly cited.

\begin{abstract}
Metal uptake by different plant species was quantified in sand media amended with biosolids in a sand-culture hydroponic medium. In a previous paper (Koo et al. 2006), we concluded that total quantities of organic acids were greatest in treatments containing both plants and biosolids, with lesser amounts in treatments with plants alone, biosolids-treated media alone, and a nutrient solutionirrigated blank medium. Biosolids enhanced organic acid production in the rhizosphere. The purpose of this study was to evaluate how organic acids in root exudates affect the absorption of metals by selected plants. We found that the concentrations of metals in the plant tissue grown on biosolids-treated medium were always higher than that from the standard medium, irrespective of species and cultivar. The amount of metal transferred from the biosolids-treated medium to the plant varied with the metal element, following the order: $\mathrm{Cd}>\mathrm{Ni}=\mathrm{Zn}>\mathrm{Cu}>\mathrm{Pb}>\mathrm{Cr}$. Interspecies and cultivar differences in metal uptake were trivial compared to differences induced by the treatment. The metal uptake decreased with the growth period, and the kinetics of metal uptake, as indicated by accumulation in corn shoots, were essentially a first order during the initial 4 weeks of growth, especially for Cd and Zn.
\end{abstract}

\section{Introduction}

The chemical and biological reactions occurring in the soilroot interface play an important role in the availability of metals to plants [1]. Metal uptake by plants depends on both edaphic and plant factors. Edaphic factors include metal concentration in soil, interactions of metal with the soil (solid) surfaces, and the $\mathrm{pH}$ at the root-soil interface. Plant roots may change the physical, chemical, and biological conditions of the soil immediately adjacent to the root, commonly referred to as the rhizosphere. The rhizosphere, in comparison to bulk soil, is enriched with organic substances of plant and microbial origin. They include organic acids, sugars, amino acids, lipids, coumarins, flavonoids, proteins, enzymes, aliphatics, aromatics, and carbohydrates [2-6]. Among them, the organic acids are the most abundant and highly chemically reactive with soil constituents. The commonly found organic acids in the rhizosphere are acetic, butyric, citric, fumaric, lactic, malic, malonic, oxalic, propionic, tartaric, and succinic acids [5, 7-9]. In soils, organic acids are involved in biogeochemical processes that release the not-so-readily available nutrients such as phosphorus, iron, and other micronutrients for plant nutrition [10-12].

Organic acids in the rhizosphere affect the translocation of metal elements in soil [13-15]. They influence the acidification, metal chelation, precipitation, and oxidation-reduction reactions in the rhizosphere. Thus, they influence the solubility and plant uptake of metals, the dynamics of microbial activity, rhizosphere physical properties, and root morphology. There is increasing evidence that root exudates increase the solubility of metals in the rhizosphere. Linehan et al. [16] reported that concentrations of $\mathrm{Cu}, \mathrm{Zn}, \mathrm{Mn}$, and $\mathrm{Co}$ in soil solution increased when plants were present. Morel et al. [17] and Mench et al. [18, 19] showed that corn root exudates, for example, were capable of binding $\mathrm{Cd}$ in soil.

In land application of biosolid, metals are added into the soil mainly associated with solid particles. In this case, plant absorption of biosolids-borne metals may take place through root extraction from those present in bulk soil solution via solid-solution phase equilibration or at the rhizosphere and soil interface where root exudates mobilize the solid phase metals. Considering that metal concentrations in the soil 
solution are typically low and dissolution kinetics for metals in soils are also commonly slow, metal absorption from the bulk soil solution may not be the most predominant process by which metals are taken up by plants grown in biosolidstreated soils. Accordingly, Eaton [20] reported that plants grown in sand nutrient culture obtained Fe and P from waterinsoluble minerals by absorption across the particle-root interface rather than by absorption directly from the culture or soil solution. Mench and Martin [21] found that soil $\mathrm{Cd}, \mathrm{Cu}$, $\mathrm{Fe}, \mathrm{Mn}, \mathrm{Ni}$, and $\mathrm{Zn}$ were solubilized and therefore facilitated their uptake by root exudates of Nicotiana tabacum, N. rustica, and Zea mays. They also reported that Cd concentrations in these plant species were proportional to the amounts of $\mathrm{Cd}$ extracted from the soil in which they were grown. Likewise, Krishnamurti et al. [22] demonstrated that soil Cd was mobilized by low-molecular-weight organic acids such as acetic, citric, oxalic, fumaric, and succinic acids often found in root exudates. At the same concentration, they found that Cd released from the soil by organic acids followed the order: fumaric $>$ citric $>$ oxalic $>$ acetic $>$ succinic.

As plants develop and roots grow in soil, biogeochemical reactions are dynamically changing. These changes, in turn, may affect the availability of metals in the growth medium and their subsequent uptake by plant. For example, Koo et al. [5] demonstrated that the nature and diversity of organic acids from root exudates were affected by the growth stage of the plant. Since organic acids are known to influence the mobility of metals in soil, the purpose of this study is to elucidate how the length of plant growing period, plant species, and cultivars affect the availability of metals to plants grown on biosolids-treated medium.

\section{Materials and Methods}

2.1. Culture Medium, Nutrient Solution, and Statistical Analyses. Experiments were conducted in a glasshouse in which corn plants (Zea mays L.) were cultured on a sand medium irrigated with a nutrient solution and on biosolids-treated sand media that were irrigated with the same nutrient media minus trace metals ( $\mathrm{Zn}, \mathrm{Cu}, \mathrm{Mn}$, and $\mathrm{Ni}$ ). Plants were cultivated under septic conditions, and no attempt was made to control the microbial population in the culture media.

Each hydroponic-culture unit consisted of a reservoir containing 100 liters of nutrient solution that supported four 10-liter size plastic pots on the cover plate of the nutrient solution reservoir. Each plastic pot had a standpipe to control the water level and prevent overflow during irrigation and perforations at the bottom for gravity drainage back into the nutrient solution reservoir. Pots in the same treatment level received separate biosolid treatment and were irrigated with the common irrigation solution. A biosolid compost produced by the Metropolitan Wastewater Reclamation District of Greater Chicago in 1975 was air dried and used at a rate equivalent to $20 \mathrm{Mg} \mathrm{ha}^{-1}$ in all experiments. This biosolid has been a reference material for multiple state and year studies in the past [23], and it has considerably higher metal contents than the contemporary biosolids. For the phosphate rock treatment, the amendment in powder form was incorporated at the equivalent rate of $150 \mathrm{~kg} \mathrm{Pha}^{-1}$. The total $\mathrm{C}$ and $\mathrm{N}$ content of this biosolid was $8.9 \%$ and $0.8 \%$, respectively. The concentrations of selected metals ( $\mathrm{mg} \mathrm{kg}^{-1} \mathrm{dw}$ ) in this compost are as follows: As, $23 \pm 1$; Cd, 119 \pm 12 ; Cr, 1, 556 \pm 202 ; Cu, 767 \pm 92 ; $\mathrm{Ni}, 482 \pm 31$; Pb, 1, $344 \pm 40$; Se, $2.8 \pm 0.3$; and $\mathrm{Zn}, 4,390 \pm 274$. All of the biosolids were air dried and screened to pass a $2 \mathrm{~mm}$ sieve prior to use. The added biosolids amendments were mixed with the top two-thirds of the sand in each pot, leaving the bottom one-third as a buffer to prevent the amendments from being washed into the nutrient solution reservoir. An automated watering system was set up so that the nutrient solution was pumped from the reservoir at preset time intervals to irrigate plants growing on the sand medium 5 times per day. After irrigation, excess nutrient solution drained into the reservoir by gravity. The stored nutrient solution was continuously aerated.

A modified Hoagland solution was used as the standard nutrient solution (in mM): $2.0 \mathrm{Ca}\left(\mathrm{NO}_{3}\right)_{2}, 2.0 \mathrm{KCl}, 0.5$ $\mathrm{MgSO}_{4}, 0.1 \mathrm{NaCl}, 1.0 \mathrm{C}_{6} \mathrm{H}_{13} \mathrm{NSO}_{4}$ buffer, $0.2 \mathrm{NaH}_{2} \mathrm{PO}_{4}, 0.012$ $\mathrm{Zn}$ as $\mathrm{ZnCl}_{2}, 0.15 \mathrm{Fe}$ as $\mathrm{Fe}\left(\mathrm{NO}_{3}\right)_{3}, 0.006 \mathrm{Mn}$ as $\mathrm{MnCl}_{2}, 0.002$ $\mathrm{Cu}$ as $\mathrm{CuCl}_{2}, 0.0001 \mathrm{Ni}, 0.01 \mathrm{H}_{3} \mathrm{BO}_{3}$, and $0.0001 \mathrm{Na}_{2} \mathrm{MoO}_{4}$ $[24,25]$. Amounts of ethylenediaminetetra acetic acid (HEEDTA) were added to match trace element nutrient solution concentrations. For the biosolid treatment, $\mathrm{Zn}, \mathrm{Mn}, \mathrm{Cu}$, and Ni along with HEEDTA were withheld from the nutrient solution as the biosolids contained significant amounts of trace elements. The $\mathrm{pH}$ of the nutrient solution was checked routinely and maintained at $\mathrm{pH} 6$ with $\mathrm{HCl}$ and $\mathrm{NaOH}$. During the course of growth, the nutrient levels in the reservoir were checked and replenished biweekly during the first 4 weeks, weekly during the period between 4 and 8 weeks, and twice per week for the remainder of the growing period.

The experiments were set up in blocks. Within each block, it followed the factorial design, with biosolid treatments (nutrient solution versus nutrient solution + biosolids) and plants (blank versus planted) as the factors. The four pots in each treatment combination received separate biosolid treatments and irrigated with the modified Hoagland nutrient solution, from a common reservoir, that represents the controlled condition. These four pots are replicates in terms of the biosolid treatments. For the experiment, each tank was sampled at a given date that represented a treatment level, and the four pots represented four observations made with this treatment level. Student's $t$-tests were used to differentiate the difference between the control and the treatment. When the differences with respect to time were considered at the end of the experiment, the data of each treatment was treated as a one-way analysis of variance (ANOVA) and the time was treated as the incremental treatment levels. Tukey's multiple range test determined whether the treatment, were significantly different from one another. Similar approaches were employed to analyze data of the second experiment in which each biosolid was a separate treatment. The outcomes of each biosolid were compared with the control using Student's $t$ test. Again, the differences with respect to time for each treatment were tested using one-way ANOVA.

2.1.1. Plant Species Used. Depending on the experiment, corn (Zea mays L.), durum wheat (Triticum turgidum L.), rape (Brassica napus L.), Sudan grass (Sorghum sudanense L.), 
chickpea (Cicer arietinum L.), and Swiss chard (Beta vulgaris L.) were grown on the three different sand media. Seeds were placed on moist germination towels, rolled up, and incubated in a growth chamber. Following germination, the towels were unwrapped and the root length of each seedling was measured. Seedlings with approximately the same root length were selected for planting; 3-5 day old seedlings were transferred to pots and root exudates were collected at preset times following planting. At each sampling date, plants were removed from the sand culture system for root exudate and plant tissue collection.

2.2. Biomass and Plant Tissue Samples. At the time of harvesting, plants were removed from the pots, separated into shoot and root portion, rinsed with deionized water, dried to constant weight at $65^{\circ} \mathrm{C}$ for 5 days, and weighed for biomass determination. For metal analysis using Inductively Coupled Plasma Optical Emission Spectroscopy (ICP-OES) and Atomic Absorption Spectrophotometry (AAS), aliquots of plant tissue were digested in Teflon Parr bombs by a $\mathrm{HNO}_{3}$ microwave digestion procedure $(0.25 \mathrm{~g}$ dried tissue with a mixture of $2.0 \mathrm{~mL}$ concentrated $\mathrm{HNO}_{3}+2.0 \mathrm{~mL} \mathrm{H} \mathrm{H}_{2}+$ $1.0 \mathrm{~mL} \mathrm{H}_{2} \mathrm{O}$ in a $120 \mathrm{~mL}$ Teflon digestion vessel for 15 minutes and with maximum pressure of $1,037 \mathrm{kPa}$ ) [26].

\section{Results and Discussion}

\subsection{Plant Uptake of Biosolid-Borne Metals}

3.1.1. Metal Uptake by Corn Grown on Biosolid-Treated Medium. When corn plants were grown from seed to maturity on the sand medium without biosolids and biosolids-treated medium, metal concentrations in the root were considerably higher than those in shoot (Table 1). Plants grown on biosolids-treated medium had significantly higher concentrations of metals than those grown on the sand medium without biosolids at all stages of growth. In plant tissue, accumulations of $\mathrm{Cd}$ (in shoots and roots) and $\mathrm{Ni}$ (in roots) were especially high for plants that received the biosolids treatment. Except for Cd in shoots and roots of plants grown on biosolids-treated medium and $\mathrm{Zn}$ in shoots and roots of plants grown on the sand medium without biosolids and in roots of plants grown on biosolids-treated medium, there was a trend for metal concentration in the plant tissue to decrease with the length of growing period (Table 1). This decrease is an indication of mass dilution when metal availability in the nutrient medium did not keep pace with the rate of biomass accumulation. For metals that were either not readily available to the plant (such as $\mathrm{Pb}$ or $\mathrm{Cr}$ ) or present only in limited amounts (such as $\mathrm{Cd}$ in the sand medium without biosolids), the amount of metals absorbed appeared to be limited by their supply in the nutrient medium. However, for metals that were in chemical forms readily available to plants and in abundant supply in the nutrient medium (such as Cd in biosolids-treated medium or $\mathrm{Zn}$ in both sand medium without biosolids and biosolids-treated medium), the metal concentration of plant tissue either continued to rise with plant growth (such as $\mathrm{Zn}$ in shoots of corn grown on both the sand medium
TABLE 1: Metal concentrations (means \pm SD where $n=4$ ) of corn tissues grown on sand media amended, without biosolids (Standard) and with biosolids ${ }^{\dagger}$.

\begin{tabular}{|c|c|c|c|}
\hline \multirow{3}{*}{ Plant tissue } & \multirow{3}{*}{ Treatment } & \multicolumn{2}{|c|}{ Time (weeks) } \\
\hline & & $0-4$ & 4-16 \\
\hline & & \multicolumn{2}{|c|}{$\mathrm{mg} \mathrm{kg}^{-1}$} \\
\hline & & \multicolumn{2}{|c|}{$\mathrm{Cd}$} \\
\hline \multirow{2}{*}{ Shoot } & Standard & $0.38(0.04)^{\mathrm{a}}$ & $0.03(0.004)^{\mathrm{b}}$ \\
\hline & Biosolids & $7.25(1.27)^{\mathrm{b}}$ & $9.50(1.09)^{\mathrm{a}}$ \\
\hline \multirow{2}{*}{ Root } & Standard & $1.85(0.31)^{\mathrm{a}}$ & $0.20(0.02)^{\mathrm{b}}$ \\
\hline & Biosolids & $36.5(4.06)^{\mathrm{b}}$ & $60.7(2.82)^{\mathrm{a}}$ \\
\hline \multirow{3}{*}{ Shoot } & & \multicolumn{2}{|c|}{$\mathrm{Cr}$} \\
\hline & Standard & $1.20(0.11)^{\mathrm{a}}$ & $0.83(0.03)^{\mathrm{b}}$ \\
\hline & Biosolids & $2.70(0.49)^{\mathrm{a}}$ & $1.43(0.06)^{\mathrm{b}}$ \\
\hline \multirow{2}{*}{ Root } & Standard & $1.80(0.14)^{\mathrm{a}}$ & $1.17(0.07)^{\mathrm{b}}$ \\
\hline & Biosolids & $13.5(0.84)^{\mathrm{a}}$ & $6.00(1.42)^{\mathrm{b}}$ \\
\hline \multirow{3}{*}{ Shoot } & & \multicolumn{2}{|c|}{$\mathrm{Cu}$} \\
\hline & Standard & $12.0(0.55)^{\mathrm{a}}$ & $6.67(0.13)^{\mathrm{b}}$ \\
\hline & Biosolids & $17.0(0.55)^{\mathrm{a}}$ & $12.7(0.80)^{\mathrm{b}}$ \\
\hline \multirow{2}{*}{ Root } & Standard & $22.0(1.45)^{\mathrm{a}}$ & $18.3(1.20)^{b}$ \\
\hline & Biosolids & $63.5(6.70)^{\mathrm{a}}$ & $40.3(3.97)^{\mathrm{b}}$ \\
\hline \multirow{3}{*}{ Shoot } & & \multicolumn{2}{|c|}{$\mathrm{Ni}$} \\
\hline & Standard & $14.5(0.90)^{\mathrm{a}}$ & $9.00(0.57)^{\mathrm{b}}$ \\
\hline & Biosolids & $44.0(4.65)^{\mathrm{a}}$ & $23.3(2.01)^{\mathrm{b}}$ \\
\hline \multirow{2}{*}{ Root } & Standard & $19.5(2.15)^{\mathrm{a}}$ & $12.7(0.60)^{\mathrm{b}}$ \\
\hline & Biosolids & $276(49.5)^{\mathrm{a}}$ & $149(41.7)^{\mathrm{b}}$ \\
\hline \multirow{3}{*}{ Shoot } & & \multicolumn{2}{|c|}{$\mathrm{Pb}$} \\
\hline & Standard & $5.50(0.65)^{\mathrm{a}}$ & $3.33(0.27)^{\mathrm{b}}$ \\
\hline & Biosolids & $13.5(1.01)^{\mathrm{a}}$ & $9.33(0.71)^{\mathrm{b}}$ \\
\hline \multirow{2}{*}{ Root } & Standard & $5.50(0.65)^{\mathrm{a}}$ & $2.33(0.37)^{\mathrm{b}}$ \\
\hline & Biosolids & $27.1(1.95)^{\mathrm{a}}$ & $11.1(0.27)^{\mathrm{b}}$ \\
\hline \multirow{3}{*}{ Shoot } & & \multicolumn{2}{|c|}{$\mathrm{Zn}$} \\
\hline & Standard & $30.0(1.15)^{\mathrm{b}}$ & $39.3(0.73)^{\mathrm{a}}$ \\
\hline & Biosolids & $161(9.50)^{b}$ & $295(9.67)^{\mathrm{a}}$ \\
\hline \multirow{2}{*}{ Root } & Standard & $58.5(2.00)^{\mathrm{b}}$ & $120(5.00)^{\mathrm{a}}$ \\
\hline & Biosolids & $211(15.5)^{\mathrm{a}}$ & $158(3.67)^{\mathrm{b}}$ \\
\hline
\end{tabular}

${ }^{\dagger}$ The differences of metal concentrations among the growth periods were tested by one-way ANOVA and Student-Newman-Keuls test. Within a row and between shoot and root, values followed by different letters were significantly different at $P<0.05$.

without biosolids and biosolids-treated medium and in root of the sand medium without biosolids) or remained at the same level throughout the growing period (such as $\mathrm{Zn}$ in root of grown on biosolids-treated medium). For example, $\mathrm{Zn}$ in shoots and roots of corn grown on the sand medium without biosolids and in the shoot of the biosolids-treated medium increased with time following planting. Zinc concentrations in the roots of corn grown on biosolids-treated medium, however, either remained the same or decreased slightly with time following planting (Table 1).

The amounts of metal transferred from the biosolidstreated medium to the corn varied with the metal elements. 
Based on the mass of metals that was present in the plant growth medium and absorbed by corn, the percentage of the biosolids-borne metals in the rhizosphere that was absorbed by corn was calculated (Figure 1). They were indicators of the phytoavailability of biosolids-borne metals and followed the order: $\mathrm{Cd}>\mathrm{Ni}=\mathrm{Zn}>\mathrm{Cu}>\mathrm{Pb}>\mathrm{Cr}$. For corn seedlings grown to maturity on biosolids-treated medium, the amounts of metals absorbed by the plants were 14.2, 0.01, 1.63, 9.77, 1.36, and $8.60 \%$ of total $\mathrm{Cd}, \mathrm{Cr}, \mathrm{Cu}, \mathrm{Ni}, \mathrm{Pb}$, and $\mathrm{Zn}$ in the rhizosphere, respectively. In the root environment, mucigel was reported to be an accumulation site for heavy metals [6, 27]. Mucigel can modify the flux of metal cations to the root. Due to the viscous nature of this compound, diffusion of metals can probably be hindered. Furthermore, because of complexing reactions, diffusion of metals (such as $\mathrm{Pb}$ and $\mathrm{Cu}$ ) having high affinity for the mucilage can decrease in the rhizosphere, while Cd could easily diffuse to the root surface. This way mucigels can act as a selective filter for metals. Morel et al. [27] reported that $\mathrm{Pb}$ uptake by corn was minimal despite its high concentration in biosolids-treated soil, compared to $\mathrm{Cd}$. Similarly, Cd and $\mathrm{Zn}$ can readily form organometallic complexes with organic acids from root exudates facilitating their diffusion to roots [28].

The how availability of $\mathrm{Pb}$ and $\mathrm{Cr}$ to corn in biosolidstreated soil can be explained by the formation of relatively stable complexes or chelation that results from the interaction with organic matter and redox reaction in the case of Cr. Certain metals (e.g., $\mathrm{Cu}$ and $\mathrm{Pb}$ ) exhibit high affinities for soil organic matter, where soluble and insoluble complexes between the metals and organic matter may form. Thus, indigenous soil organic matter and the added biosolids can affect the binding ability for metals in biosolids-treated soils. The majority of $\mathrm{Pb}$ immobilized by biosolids-treated soils is believed to be associated with organic matter [29]. Then, because of the strong affinity of $\mathrm{Pb}$ for organic matter and its generally immobile nature, $\mathrm{Pb}$ can be expected to accumulate in the surface layer of biosolids-treated soils and is less phytoavailable. Chang et al. [30] found that in cropped soils treated continuously for 6 years with municipal sewage sludge, $>90 \%$ of the applied $\mathrm{Pb}$ was found in the surface 0 to $15 \mathrm{~cm}$, the zone of application. In contrast to $\mathrm{Pb}$, biosolids treatment in soil resulted in significant increase in uptake of $\mathrm{Cd}, \mathrm{Ni}$, and Zn by plant tissues, since biosolids lead to higher acidification of rhizosphere by release of organic acids [5, 21, 31].

The moisture content of soils also influences their retention for metals (e.g., $\mathrm{Cr}$ and $\mathrm{Mn}$ ) through oxidation-reduction reactions. Hexavalent chromium, $\mathrm{Cr}(\mathrm{VI})$, is more soluble and mobile in soils and more available to plants than trivalent chromium, Cr(III). While Cr(III) strongly binds with soil particles, $\mathrm{Cr}(\mathrm{VI})$ is very weakly adsorbed and therefore readily available for plant uptake [32]. Chromium(VI) can be reduced to $\mathrm{Cr}$ (III) in the biosolids-treated soils because of the presence of organic matter acting as an electron donor $[33,34]$. Bolan et al. [35] demonstrated that the addition of organic manure enhanced reduction of $\mathrm{Cr}(\mathrm{VI})$ to $\mathrm{Cr}(\mathrm{III})$ that resulted in higher insoluble fractions and lower plant uptake of the element from soils. Although atypical of arable land condition, elemental concentrations in soil solution extracted similarly from biosolids-treated soil indicated the decreased

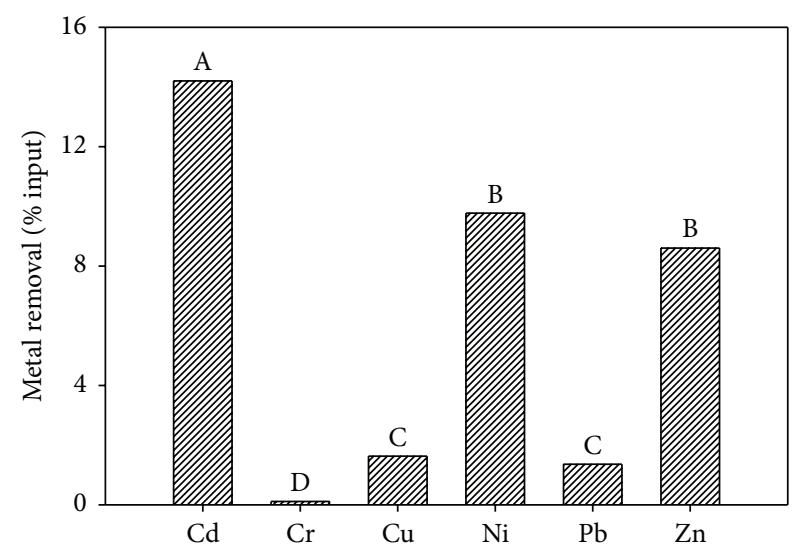

FIGURE 1: Metal removal by corn shoot and root grown on sand media amended with biosolids.

solubility of $\mathrm{Cd}, \mathrm{Cu}$, and $\mathrm{Zn}$ but increased solubility of $\mathrm{Mn}$ and $\mathrm{Cr}$ under reducing conditions [36].

The rate of metal uptake, measured as the amount of metal absorbed per unit biomass (data in [5]), increased during the plant growing period $\left(\mu \mathrm{gg}^{-1} 2 \mathrm{wk}^{-1}\right)$ (Table 2$)$. The rates of absorption of Cd in shoots of corn grown on biosolids-treated medium and $\mathrm{Zn}$ in shoots of corn grown on the sand medium without biosolids remained rather constant for the first 8-12 weeks. For Cd accumulation in shoots and roots in the sand medium without biosolids where the supply was limited, there was insignificant additional Cd uptake after the first 4 weeks of growth, after which additional uptake was not detected (Table 2). When the Cd supply was not limiting (i.e., biosolids treatments), the uptake rate of $\mathrm{Cd}$ remained relatively constant over the entire growing period (0-12 weeks for roots and $0-16$ weeks for shoots). When $\mathrm{Zn}$ supply was not limiting (such as shoots in the sand medium without biosolids and biosolids-treated medium), the uptake rate of $\mathrm{Zn}$ by corn shoots also remained constant over the same period. Toward the end the growing season, however, there was a tendency for the accumulation rate of the shoot to rise as the production of biomass slowed down, while at the same time the transpiration and translocation of metals continued.

The uptake rate for $\mathrm{Zn}$ was considerably higher than that for Cd (Table 2); the latter rates for shoots and roots from biosolids treatment were 5-7 and $25-79 \mu \mathrm{gg}^{-1} 2 \mathrm{wk}^{-1}$, respectively, and the rates from the same treatment for $\mathrm{Zn}$ were 127-687 and $31-235 \mu \mathrm{g} \mathrm{g}^{-1} 2 \mathrm{wk}^{-1}$ for shoots and roots, respectively. In the sand medium without biosolids where $\mathrm{Zn}$ was supplied, the $\mathrm{Zn}$ accumulation in shoots remained steady until the 12th week. The biosolid and nutrient solution represent different source term for the heavy metals of interest. While metals in nutrient solution are totally soluble, those in the biosolids had to be solubilized before they become phytoavailable. Despite this discrepancy in the source term, $\mathrm{Zn}$ uptake from biosolid was substantially higher $\left(127-687 \mu \mathrm{g} \mathrm{g}^{-1}\right.$ $2 \mathrm{wk}^{-1}$ ) than from the solution (19-63 $\left.\mu \mathrm{gg}^{-1} 2 \mathrm{wk}^{-1}\right)$. In the sand medium without biosolids, $\mathrm{Pb}$ was not supplied but was present in the trace amounts in reagents used. Thus, the amount of $\mathrm{Pb}$ absorbed appeared to be limited by their supply 
TABLE 2: Metal uptake rates (means where $n=4$ ) by corn grown on sand media amended, without biosolids (Standard) and with biosolids at different growth stages ${ }^{\dagger}$.

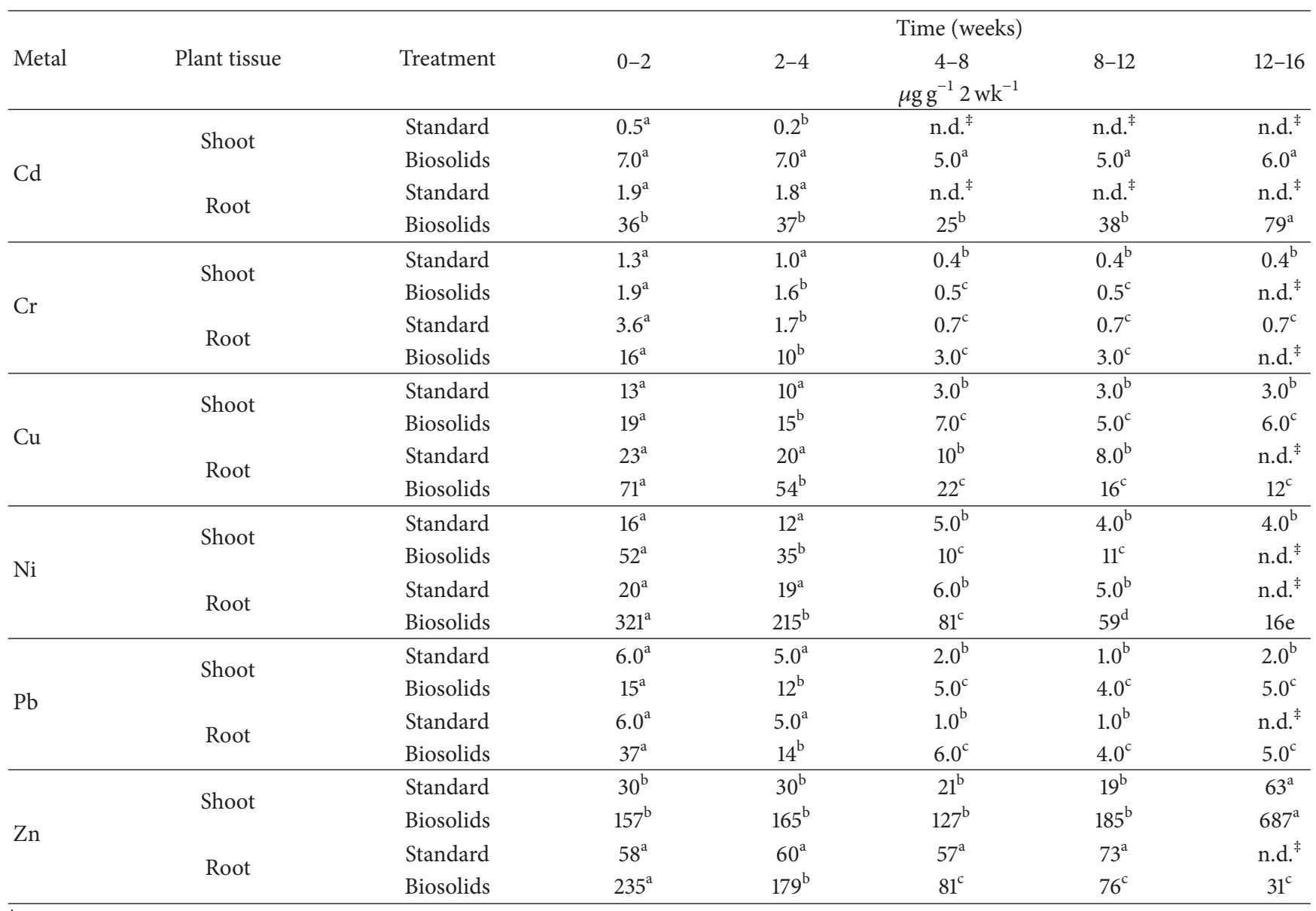

${ }^{\dagger}$ The differences of metal rates among the time periods were tested by one-way ANOVA. Within a row and between shoot and root, values followed by same letters were not significantly different at $P<0.05$.

${ }^{\ddagger}$ Metal uptake rate was not detected in this period.

in the growing medium, resulting in its uptake continuously decreasing over the entire growing period of $0-8$ weeks (Table 2).

The uptake rates for $\mathrm{Cr}, \mathrm{Cu}, \mathrm{Ni}$, and $\mathrm{Pb}$ by corn shoots and roots from biosolids-treated medium decreased with the increasing length of growing period (Table 2). It appeared that the solution concentration of these metals and, therefore, its availability to the corn, were controlled by the rate of dissolution of biosolids-borne metals. Their uptake rates tended to follow a first order reaction model in that the rate of uptake gradually decreased over time as their available pool progressively diminished in the rhizosphere. Once the available pool was exhausted, the rate of $\mathrm{Cr}$ and $\mathrm{Pb}$ absorption decreased considerably. The persistent low concentrations of $\mathrm{Pb}$ and $\mathrm{Cr}$ in the aqueous phase of the sand indicate their slow dissolution/desorption kinetics from the biosolid.

Among the metals, $\mathrm{Cd}$ and $\mathrm{Zn}$ generally accumulated in plant tissue due to their high contents in biosolids, their mobility, and ease of uptake by the plants. On the other hand, $\mathrm{Cu}$, $\mathrm{Cr}, \mathrm{Ni}$, and $\mathrm{Pb}$ exhibited decreased uptake due to their unavailable nature from the biosolids. Because of similarity in the biogeochemical behavior of $\mathrm{Zn}$ and $\mathrm{Cd}$ in biosolids-treated soils, they exhibited a similar pattern of uptake in plants [29]. Metal contents of crops grown on biosolids-treated soils are generally a function of the annual biosolids loading rate. However, long-term changes in certain soil properties can also occur to affect the biogeochemical behavior of the metals. For example, an increase in soil $\mathrm{pH}$ can reduce metal phytoavailability and accumulation in plant tissue in spite of a progressive rise in the total metal contents in soil. The cumulative metal input into the soil is also a major factor determining metal uptake by plants $[5,37,38]$. Perceived as typical for biosolids-borne metals, metal concentration in plant tissue may approach a leveling pattern (i.e., a plateau) with progressive metal input, indicating some buffering influence of the biosolids organic matter on phytoavailability. In this respect, Chang et al. [38] established a nonlinear regression model for Swiss chard, radish, and tubers grown in a long-term experiment where composted municipal sewage sludge was applied, at increasing rate, into the soil.

3.1.2. Metal Uptake by Wheat Cultivars Grown on BiosolidTreated Medium. The metal concentration in the plant tissue of three wheat varieties (e.g. cv. Chinese Spring, cv. Yecora 
Rojo, and Triticum aestivum) varied with the treatment, metal element, plant part, and length of plant growth. In general, the metal concentrations in tissues harvested from the biosolids treatment were higher or equal than those from the sand medium without biosolids (Table 3). As expected, metal concentrations in the roots of the wheat cultivars at 4 th, 8 th, and 12th week were considerably higher than those in the corresponding shoots except for $\mathrm{Cd}$ and $\mathrm{Cr}$, which were similar in both tissues when grown on the sand medium without biosolids. In all cases, metal concentrations in tissues of the cultivars were highest at the 4 th week, decreasing progressively afterward.

Intertreatment differences among the metal contents were greater than the intercultivar differences (Table 3). For example, total uptake of metals in the shoots from the biosolids treatment varied by factor of 2-3 (Figure 2). Based on the differences between the mass of metals present in the growth medium and that absorbed by wheat tissue, the percentage of metals that was absorbed could be calculated. It became apparent that the extent of phytoavailability of the metals derived from the biosolid follows the order: $\mathrm{Cd}>\mathrm{Ni}=$ $\mathrm{Zn}=\mathrm{Cu}>\mathrm{Pb}>\mathrm{Cr}$ (Figure 2). The least bioavailability of $\mathrm{Pb}$ and $\mathrm{Cr}$ to plants follows the general trend reported in the literature because of their strong complexation with organic matter compounds [29] and more specifically the effective role of organic matter, in this case in the form of biosolid, to serve as electron donor for the reduction of $\mathrm{Cr}(\mathrm{VI})$ to its immobile and largely unavailable form, Cr(III) [35]. A similar trend for corn (Figure 1) grown on biosolids-treated medium was observed. Because of the lower biomass, the amounts of metals removed by wheat plants were considerably lower than that for corn (Table 2). In general, cv. Chinese Spring removed greater amounts of metals than the other two cultivars (Figure 2). The total content in shoots followed the following order:

Cd: cv. Chinese Spring = Triticum aestivum $>\mathrm{cv}$. Yecora Rojo

Cr: cv. Chinese Spring = Triticum aestivum $>\mathrm{cv}$. Yecora Rojo

Cu: cv. Chinese Spring > Triticum aestivum $=\mathrm{cv}$. Yecora Rojo

Ni: cv. Chinese Spring > Triticum aestivum $=\mathrm{cv}$. Yecora Rojo

Pb: cv. Chinese Spring > Triticum aestivum > cv. Yecora Rojo

Zn: cv. Chinese Spring > Triticum aestivum > cv. Yecora Rojo.

The higher uptake by cv. Chinese Spring can be attributed to its longer vegetative growth period. For example, cv. Yecora Rojo and Triticum aestivum reached maturity at the 10-12 week, while cv. Chinese Spring did not reach maturity till the end of the 12th week.

Generally, the uptake rates for the wheat cultivars varied with the growth period (Table 4). Except for $\mathrm{Pb}$ and $\mathrm{Cr}$, uptake was higher at the earlier part of the growth period ( $0-4$ weeks), decreasing over time. Again, this indicates the lower

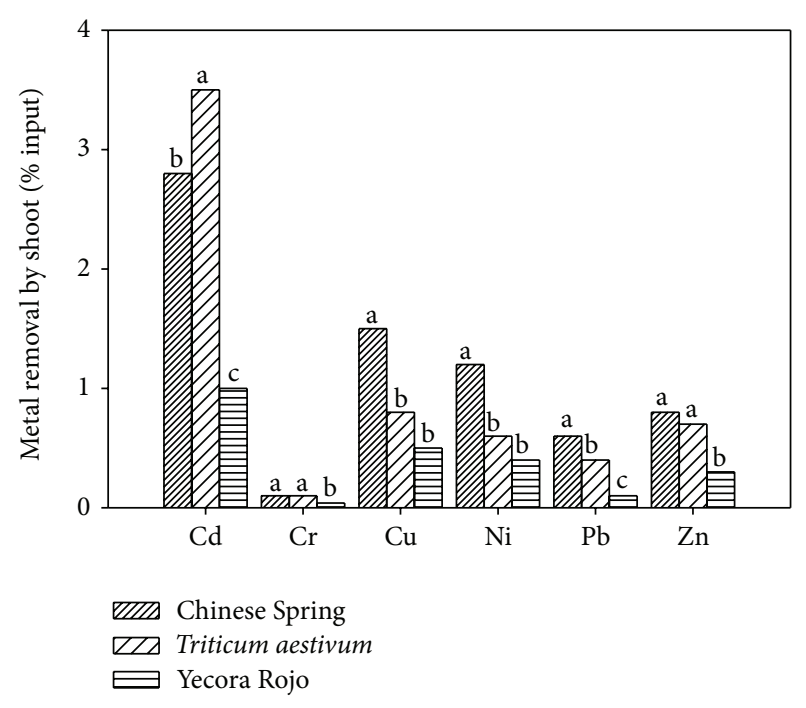

FIGURE 2: Metal removal by shoots of three wheat cultivars grown on sand media amended with biosolids for 12 weeks (the differences of metal removal among the wheat cultivars were tested by oneway ANOVA test and values followed by same lower letter were not significant different at $P<0.05$ ).

solubility and subsequent availability of $\mathrm{Pb}$ and $\mathrm{Cr}$ from the biosolid to the plant.

3.1.3. Metal Uptake by Six Plant Species Grown on BiosolidTreated Medium. Six plants (Zea mays, Triticum turgidum, Brassica napas, Sorghum sudanense, Cicer arietinum, and Beta vulgaris) grown on biosolids-treated medium accumulated greater amounts of metals in both shoots and roots compared to the sand medium without biosolids and phosphate rock treatments (Table 5). The metal concentrations in roots were considerably higher than in the shoots. Generally, metal concentrations in plant tissues for respective treatments were biosolids-treated $>$ phosphate rock-treated $=$ sand medium without biosolids. The monocots (Zea mays, Sorghum sudanense, and Triticum turgidum) were not able to use the $\mathrm{P}$ in phosphate rock as effectively as the $\mathrm{P}$ from the nutrient solution (Table 6), consequently lowering the biomass yield [5]. On the other hand, dicots (Cicer arietinum, Brassica napas, and Beta vulgaris) used the $\mathrm{P}$ in phosphate rock more effectively. These discrepancies resulted in the $\mathrm{P}$ availability following the trend: phosphate rock-treated > biosolids-treated > sand medium without biosolids for the dicots and biosolids-treated $>$ phosphate rock-treated $=$ sand medium without biosolids for the monocots (Table 6). Unlike the metals, the P concentrations in the shoots were considerably higher than those in the roots.

The organic acids in root exudates are considered important for the solubilization of sparingly soluble $\mathrm{P}$ in phosphate rock [5]. The factors most likely to limit phosphate rock dissolution are insufficient $\mathrm{pH}$ buffering and/or $\mathrm{P}$ sorption capacity and increase in $\mathrm{Ca}^{2+}$ activity in the soil solution around phosphate rock particles. Phosphate rocks have been reported to be more effective in supplying $\mathrm{P}$ to dicots (i.e., white clover) than to monocots (i.e., wheat and barley) $[5,39]$. 
TABLE 3: Metal concentrations (means where $n=4$ ) of three wheat cultivars grown on sand media amended, without biosolids (Standard) and with biosolids ${ }^{\dagger}$.

\begin{tabular}{|c|c|c|c|c|c|c|c|}
\hline \multirow[b]{2}{*}{ Plant tissue } & \multirow[b]{2}{*}{ Treatment } & \multicolumn{6}{|c|}{ Duration (weeks) } \\
\hline & & $\begin{array}{l}\text { Chinese } \\
\text { Spring }\end{array}$ & $\begin{array}{c}0-4 \\
\text { Triticum } \\
\text { aestivum }\end{array}$ & $\begin{array}{l}\text { Yecora } \\
\text { Rojo }\end{array}$ & $\begin{array}{l}\text { Chinese } \\
\text { Spring }\end{array}$ & $\begin{array}{c}4-12 \\
\text { Triticum } \\
\text { aestivum }\end{array}$ & $\begin{array}{c}\text { Yecora } \\
\text { Rojo }\end{array}$ \\
\hline & & \multicolumn{6}{|c|}{$\mathrm{Cd}$} \\
\hline Shoot & $\begin{array}{l}\text { Standard } \\
\text { Biosolids }\end{array}$ & $\begin{array}{l}2.53^{\mathrm{a}} \\
24.6^{\mathrm{a}}\end{array}$ & $\begin{array}{l}2.55^{\mathrm{a}} \\
29.8^{\mathrm{a}}\end{array}$ & $\begin{array}{l}2.56^{\mathrm{a}} \\
24.4^{\mathrm{a}}\end{array}$ & $\begin{array}{l}0.56^{\mathrm{b}} \\
6.06^{\mathrm{b}}\end{array}$ & $\begin{array}{l}0.75^{\mathrm{b}} \\
8.75^{\mathrm{a}}\end{array}$ & $\begin{array}{l}1.01^{\mathrm{a}} \\
8.47^{\mathrm{a}}\end{array}$ \\
\hline \multirow{2}{*}{ Root } & Standard & $2.63^{\mathrm{a}}$ & $2.64^{\mathrm{a}}$ & $2.84^{\mathrm{a}}$ & $0.75^{\mathrm{a}}$ & $0.78^{\mathrm{a}}$ & $0.72^{\mathrm{a}}$ \\
\hline & Biosolids & $41.8^{\mathrm{a}}$ & $39.3^{\mathrm{a}}$ & $26.1^{\mathrm{b}}$ & $18.0^{\mathrm{a}}$ & $12.9^{\mathrm{c}}$ & $15.8^{\mathrm{b}}$ \\
\hline \multirow[b]{2}{*}{ Shoot } & & \multicolumn{6}{|c|}{$\mathrm{Cr}$} \\
\hline & $\begin{array}{l}\text { Standard } \\
\text { Biosolids }\end{array}$ & $\begin{array}{l}1.75^{\mathrm{a}} \\
2.77^{\mathrm{a}}\end{array}$ & $\begin{array}{l}1.73^{\mathrm{a}} \\
2.70^{\mathrm{a}}\end{array}$ & $\begin{array}{l}1.75^{\mathrm{a}} \\
2.69^{\mathrm{a}}\end{array}$ & $\begin{array}{l}1.54^{\mathrm{a}} \\
1.51^{\mathrm{a}}\end{array}$ & $\begin{array}{l}1.15^{\mathrm{b}} \\
1.56^{\mathrm{a}}\end{array}$ & $\begin{array}{l}1.52^{\mathrm{a}} \\
1.52^{\mathrm{a}}\end{array}$ \\
\hline \multirow{2}{*}{ Root } & Standard & $1.77^{\mathrm{a}}$ & $1.76^{\mathrm{a}}$ & $1.81^{\mathrm{a}}$ & $1.45^{\mathrm{a}}$ & $1.44^{\mathrm{a}}$ & $1.44^{\mathrm{a}}$ \\
\hline & Biosolids & $34.5^{\mathrm{b}}$ & $42.7^{\mathrm{a}}$ & $33.2^{\mathrm{b}}$ & $12.2^{\mathrm{a}}$ & $9.11^{\mathrm{b}}$ & $4.99^{c}$ \\
\hline & & \multicolumn{6}{|c|}{$\mathrm{Cu}$} \\
\hline Shoot & $\begin{array}{l}\text { Standard } \\
\text { Biosolids }\end{array}$ & $\begin{array}{l}16.0^{\mathrm{a}} \\
27.7^{\mathrm{a}}\end{array}$ & $\begin{array}{l}15.5^{\mathrm{a}} \\
27.4^{\mathrm{a}}\end{array}$ & $\begin{array}{l}16.0^{\mathrm{a}} \\
20.0^{\mathrm{b}}\end{array}$ & $\begin{array}{l}4.44^{\mathrm{b}} \\
9.50^{\mathrm{a}}\end{array}$ & $\begin{array}{l}4.46^{\mathrm{b}} \\
7.73^{\mathrm{b}}\end{array}$ & $\begin{array}{l}5.07^{\mathrm{a}} \\
6.41^{\mathrm{c}}\end{array}$ \\
\hline \multirow{2}{*}{ Root } & Standard & $17.4^{\mathrm{a}}$ & $17.3^{\mathrm{a}}$ & $17.7^{\mathrm{a}}$ & $12.0^{\mathrm{a}}$ & $12.5^{\mathrm{a}}$ & $10.3^{\mathrm{b}}$ \\
\hline & Biosolids & $79.9^{\mathrm{a}}$ & $77.1^{\mathrm{a}}$ & $77.5^{\mathrm{a}}$ & $64.8^{\mathrm{a}}$ & $59.9^{\mathrm{b}}$ & $60.9^{\mathrm{b}}$ \\
\hline & & \multicolumn{6}{|c|}{$\mathrm{Ni}$} \\
\hline Shoot & $\begin{array}{l}\text { Standard } \\
\text { Biosolids }\end{array}$ & $\begin{array}{l}21.1^{\mathrm{a}} \\
64.9^{\mathrm{a}}\end{array}$ & $\begin{array}{l}21.4^{\mathrm{a}} \\
54.6^{\mathrm{b}}\end{array}$ & $\begin{array}{l}21.2^{\mathrm{a}} \\
54.9^{\mathrm{b}}\end{array}$ & $\begin{array}{l}9.82^{\mathrm{a}} \\
40.5^{\mathrm{a}}\end{array}$ & $\begin{array}{l}9.72^{\mathrm{a}} \\
34.5^{\mathrm{b}}\end{array}$ & $\begin{array}{l}9.20^{\mathrm{a}} \\
34.3^{\mathrm{b}}\end{array}$ \\
\hline \multirow{2}{*}{ Root } & Standard & $52.5^{\mathrm{a}}$ & $52.6^{\mathrm{a}}$ & $53.7^{\mathrm{a}}$ & $34.4^{\mathrm{a}}$ & $34.6^{\mathrm{a}}$ & $35.1^{\mathrm{a}}$ \\
\hline & Biosolids & $135^{\mathrm{a}}$ & $158^{\mathrm{a}}$ & $154^{\mathrm{a}}$ & $112^{\mathrm{a}}$ & $120^{\mathrm{a}}$ & $118^{\mathrm{a}}$ \\
\hline & & \multicolumn{6}{|c|}{$\mathrm{Pb}$} \\
\hline Shoot & $\begin{array}{l}\text { Standard } \\
\text { Biosolids }\end{array}$ & $\begin{array}{l}2.62^{\mathrm{a}} \\
12.6^{\mathrm{a}}\end{array}$ & $\begin{array}{l}2.41^{\mathrm{a}} \\
10.2^{\mathrm{b}}\end{array}$ & $\begin{array}{l}2.63^{\mathrm{a}} \\
10.8^{\mathrm{b}}\end{array}$ & $\begin{array}{l}1.49^{\mathrm{b}} \\
7.49^{\mathrm{a}}\end{array}$ & $\begin{array}{l}1.41^{\mathrm{b}} \\
7.13^{\mathrm{a}}\end{array}$ & $\begin{array}{l}1.93^{\mathrm{a}} \\
6.57^{\mathrm{b}}\end{array}$ \\
\hline \multirow{3}{*}{ Root } & Standard & $2.69^{\mathrm{a}}$ & $2.72^{\mathrm{a}}$ & $2.87^{\mathrm{a}}$ & $1.67^{\mathrm{b}}$ & $2.03^{\mathrm{a}}$ & $2.23^{\mathrm{a}}$ \\
\hline & Biosolids & $14.2^{\mathrm{a}}$ & $16.2^{\mathrm{a}}$ & $16.6^{\mathrm{a}}$ & $9.24^{\mathrm{a}}$ & $10.9^{\mathrm{a}}$ & $10.0^{\mathrm{a}}$ \\
\hline & & \multicolumn{6}{|c|}{$\mathrm{Zn}$} \\
\hline \multirow{2}{*}{ Shoot } & Standard & $45.7^{\mathrm{a}}$ & $43.4^{\mathrm{a}}$ & $42.9^{\mathrm{a}}$ & $31.5^{\mathrm{a}}$ & $28.7^{\mathrm{a}}$ & $31.3^{\mathrm{a}}$ \\
\hline & Biosolids & $319^{\mathrm{a}}$ & $338^{\mathrm{a}}$ & $271^{\mathrm{b}}$ & $124^{\mathrm{a}}$ & $144^{\mathrm{a}}$ & $125^{\mathrm{a}}$ \\
\hline \multirow{2}{*}{ Root } & Standard & $68.5^{\mathrm{a}}$ & $60.3^{\mathrm{b}}$ & $51.0^{c}$ & $28.5^{\mathrm{a}}$ & $28.5^{\mathrm{a}}$ & $32.7^{\mathrm{a}}$ \\
\hline & Biosolids & $610^{\mathrm{a}}$ & $682^{\mathrm{a}}$ & $633^{\mathrm{a}}$ & $304^{\mathrm{a}}$ & $342^{\mathrm{a}}$ & $286^{\mathrm{a}}$ \\
\hline
\end{tabular}

${ }^{\dagger}$ The differences of metal concentrations among the growth period were tested by one-way ANOVA and Student-Newman-Keuls test. Within a row and between shoot and root of each growth periods, values followed by a different letter were significantly different at $P<0.05$.

TABLE 4: Metal uptake rates (means where $n=4$ ) by shoots of three wheat cultivars grown on sand media amended with biosolids ${ }^{\dagger}$.

\begin{tabular}{|c|c|c|c|c|c|c|c|}
\hline \multirow{3}{*}{ Time (week) } & \multirow{3}{*}{ Variety of wheat } & \multicolumn{6}{|c|}{ Metal accumulation } \\
\hline & & $\mathrm{Cd}$ & $\mathrm{Cr}$ & $\mathrm{Cu}$ & $\mathrm{Ni}$ & $\mathrm{Pb}$ & $\mathrm{Zn}$ \\
\hline & & \multicolumn{6}{|c|}{$\mu \mathrm{gg}^{-1} 4 \mathrm{wk}^{-1}$} \\
\hline \multirow{3}{*}{4} & Chinese Spring & $12^{\mathrm{Ac}}$ & $2^{\mathrm{Ae}}$ & $14^{\mathrm{Ac}}$ & $32^{\mathrm{Ab}}$ & $6^{\mathrm{Ad}}$ & $160^{\mathrm{Aa}}$ \\
\hline & Triticum aestivum & $15^{\mathrm{Ac}}$ & $2^{\mathrm{Ae}}$ & $14^{\mathrm{Ac}}$ & $27^{\mathrm{Ab}}$ & $5^{\mathrm{Ad}}$ & $169^{\mathrm{Aa}}$ \\
\hline & Yecora Rojo & $12^{\mathrm{Ac}}$ & $2^{\mathrm{Ae}}$ & $10^{\mathrm{Bc}}$ & $27^{\mathrm{Ab}}$ & $6^{\mathrm{Ad}}$ & $136^{\mathrm{Ba}}$ \\
\hline \multirow{3}{*}{8} & Chinese Spring & $4^{\mathrm{Bc}}$ & $1^{\mathrm{Ad}}$ & $4^{\mathrm{Ac}}$ & $23^{\mathrm{Ab}}$ & $5^{\mathrm{Ac}}$ & $96^{\mathrm{Ba}}$ \\
\hline & Triticum aestivum & $6^{\mathrm{Ac}}$ & $1^{\mathrm{Ad}}$ & $3^{\mathrm{Ac}}$ & $21^{\mathrm{Ab}}$ & $4^{\mathrm{Ac}}$ & $116^{\mathrm{Aa}}$ \\
\hline & Yecora Rojo & $7^{\mathrm{Ac}}$ & $1^{\mathrm{Af}}$ & $2^{\mathrm{Be}}$ & $21^{\mathrm{Ab}}$ & $4^{\mathrm{Ad}}$ & $104^{\mathrm{Aa}}$ \\
\hline
\end{tabular}

\footnotetext{
${ }^{\dagger}$ The differences of metal uptake rate among the wheat cultivars were tested by one-way ANOVA. In each column of each growth time for cultivars, values followed by same upper case letter were not significantly different at $P<0.05$. The differences of the metal uptake rates among the metals in same cultivars were tested by one-way ANOVA. In each row, time, and cultivar, values followed by different lowercase letter were significantly different at $P<0.05$.
} 
TABLE 5: Metal concentrations (means where $n=3$ ) of six plant species grown on sand media amended, without biosolids (Standard), with biosolids, and with phosphate rock $^{\dagger}$.

\begin{tabular}{|c|c|c|c|c|c|c|c|c|c|c|c|c|c|}
\hline \multirow[b]{2}{*}{ Plant } & \multirow[b]{2}{*}{ Treatment } & \multicolumn{2}{|c|}{$\mathrm{Cd}$} & \multicolumn{2}{|c|}{$\mathrm{Cr}$} & \multicolumn{2}{|c|}{$\mathrm{Cu}$} & \multicolumn{2}{|c|}{$\mathrm{Ni}$} & \multicolumn{2}{|c|}{$\mathrm{Pb}$} & \multicolumn{2}{|c|}{$\mathrm{Zn}$} \\
\hline & & \multicolumn{12}{|c|}{$\mathrm{mg} \mathrm{kg}^{-1}$} \\
\hline \multirow{3}{*}{ Chickpea } & Standard & $1.7^{\mathrm{b}}$ & $1.0^{\mathrm{c}}$ & $1.5^{\mathrm{b}}$ & $1.6^{\mathrm{c}}$ & $4.9^{\mathrm{b}}$ & $9.0^{\mathrm{b}}$ & $22^{\mathrm{b}}$ & $51^{b}$ & $3.1^{\mathrm{b}}$ & $6.2^{\mathrm{b}}$ & $15^{\mathrm{c}}$ & $38^{\mathrm{b}}$ \\
\hline & Biosolids & $14^{\mathrm{a}}$ & $34^{\mathrm{a}}$ & $3.7^{\mathrm{a}}$ & $17^{\mathrm{a}}$ & $16^{\mathrm{a}}$ & $51^{\mathrm{a}}$ & $50^{\mathrm{a}}$ & $172^{\mathrm{a}}$ & $9.1^{\mathrm{a}}$ & $13^{\mathrm{a}}$ & $201^{\mathrm{a}}$ & $636^{\mathrm{a}}$ \\
\hline & Phosphate rock & $1.6^{\mathrm{b}}$ & $1.7^{\mathrm{b}}$ & $0.8^{\mathrm{c}}$ & $2.1^{\mathrm{b}}$ & $4.8^{\mathrm{b}}$ & $6.8^{\mathrm{c}}$ & $3.9^{c}$ & $26^{c}$ & $2.3^{\mathrm{c}}$ & $1.5^{\mathrm{c}}$ & $25^{\mathrm{b}}$ & $36^{\mathrm{b}}$ \\
\hline \multirow{3}{*}{ Rape } & Standard & $1.9^{c}$ & $1.1^{\mathrm{c}}$ & $1.4^{\mathrm{c}}$ & $1.2^{\mathrm{c}}$ & $6.5^{\mathrm{b}}$ & $11^{\mathrm{c}}$ & $8.5^{\mathrm{b}}$ & $38^{\mathrm{b}}$ & $1.1^{\mathrm{c}}$ & $2.6^{\mathrm{b}}$ & $30^{\mathrm{b}}$ & $34^{\mathrm{b}}$ \\
\hline & Biosolids & $16^{\mathrm{a}}$ & $23^{\mathrm{a}}$ & $4.2^{\mathrm{a}}$ & $77^{\mathrm{a}}$ & $16^{\mathrm{a}}$ & $93^{\mathrm{a}}$ & $25^{\mathrm{a}}$ & $104^{\mathrm{a}}$ & $13^{\mathrm{a}}$ & $31^{\mathrm{a}}$ & $253^{\mathrm{a}}$ & $344^{\mathrm{a}}$ \\
\hline & Phosphate rock & $2.5^{\mathrm{b}}$ & $2.2^{\mathrm{b}}$ & $1.9^{\mathrm{b}}$ & $3.6^{\mathrm{b}}$ & $3.4^{\mathrm{c}}$ & $8.4^{\mathrm{b}}$ & $3.9^{c}$ & $36^{\mathrm{b}}$ & $3.6^{\mathrm{b}}$ & $1.0^{\mathrm{c}}$ & $19^{c}$ & $23^{c}$ \\
\hline \multirow{3}{*}{ Swiss chard } & Standard & $1.4^{\mathrm{c}}$ & $1.1^{\mathrm{c}}$ & $0.9^{\mathrm{b}}$ & $1.7^{\mathrm{c}}$ & $9.8^{\mathrm{b}}$ & $17^{\mathrm{b}}$ & $12^{\mathrm{b}}$ & $38^{\mathrm{b}}$ & $2.4^{\mathrm{c}}$ & $5.0^{\mathrm{b}}$ & $21^{\mathrm{b}}$ & $32^{\mathrm{b}}$ \\
\hline & Biosolids & $29^{\mathrm{a}}$ & $56^{\mathrm{a}}$ & $4.6^{\mathrm{a}}$ & $34^{\mathrm{a}}$ & $23^{\mathrm{a}}$ & $241^{\mathrm{a}}$ & $27^{\mathrm{a}}$ & $399^{\mathrm{a}}$ & $6.0^{\mathrm{a}}$ & $13^{\mathrm{a}}$ & $335^{\mathrm{a}}$ & $676^{\mathrm{a}}$ \\
\hline & Phosphate rock & $2.2^{\mathrm{b}}$ & $3.6^{\mathrm{b}}$ & $1.5^{\mathrm{b}}$ & $3.9^{\mathrm{b}}$ & $7.8^{\mathrm{c}}$ & $13^{c}$ & $4.9^{c}$ & $35^{\mathrm{b}}$ & $3.7^{\mathrm{b}}$ & $2.8^{\mathrm{c}}$ & $22^{\mathrm{b}}$ & $33^{\mathrm{b}}$ \\
\hline \multirow{3}{*}{ Corn } & Standard & $1.2^{\mathrm{c}}$ & $1.6^{\mathrm{c}}$ & $1.1^{\mathrm{b}}$ & $1.3^{\mathrm{b}}$ & $4.9^{\mathrm{b}}$ & $18^{\mathrm{b}}$ & $12^{\mathrm{c}}$ & $24^{\mathrm{c}}$ & $1.9^{\mathrm{b}}$ & $7.8^{\mathrm{b}}$ & $25^{\mathrm{b}}$ & $32^{\mathrm{b}}$ \\
\hline & Biosolids & $22^{\mathrm{a}}$ & $33^{\mathrm{a}}$ & $1.3^{\mathrm{a}}$ & $45^{\mathrm{a}}$ & $12^{\mathrm{a}}$ & $58^{\mathrm{a}}$ & $41^{\mathrm{a}}$ & $242^{\mathrm{a}}$ & $11^{\mathrm{a}}$ & $21^{\mathrm{a}}$ & $226^{\mathrm{a}}$ & $479^{\mathrm{a}}$ \\
\hline & Phosphate rock & $1.4^{\mathrm{b}}$ & $2.5^{\mathrm{b}}$ & $0.7^{\mathrm{c}}$ & $1.0^{c}$ & $4.5^{\mathrm{b}}$ & $8.6^{\mathrm{a}}$ & $20^{\mathrm{b}}$ & $40^{\mathrm{b}}$ & $2.1^{\mathrm{b}}$ & $0.2^{\mathrm{c}}$ & $22^{\mathrm{c}}$ & $18^{\mathrm{c}}$ \\
\hline \multirow{3}{*}{ Sudan grass } & Standard & $1.7^{\mathrm{c}}$ & $1.1^{\mathrm{c}}$ & $1.6^{\mathrm{a}}$ & $1.3^{\mathrm{c}}$ & $8.1^{\mathrm{b}}$ & $11^{\mathrm{b}}$ & $21^{\mathrm{b}}$ & $21^{c}$ & $1.4^{\mathrm{c}}$ & $5.1^{\mathrm{b}}$ & $27^{\mathrm{c}}$ & $29^{\mathrm{b}}$ \\
\hline & Biosolids & $20^{\mathrm{a}}$ & $29^{\mathrm{a}}$ & $1.7^{\mathrm{a}}$ & $26^{\mathrm{a}}$ & $12^{\mathrm{a}}$ & $88^{\mathrm{a}}$ & $65^{\mathrm{a}}$ & $184^{\mathrm{a}}$ & $7.0^{\mathrm{a}}$ & $11^{\mathrm{a}}$ & $316^{\mathrm{a}}$ & $598^{\mathrm{a}}$ \\
\hline & Phosphate rock & $4.9^{\mathrm{b}}$ & $3.8^{\mathrm{b}}$ & $1.6^{\mathrm{a}}$ & $1.8^{\mathrm{b}}$ & $9.2^{\mathrm{b}}$ & $11^{\mathrm{b}}$ & $22^{\mathrm{b}}$ & $45^{\mathrm{b}}$ & $2.8^{\mathrm{b}}$ & $2.2^{\mathrm{c}}$ & $51^{b}$ & $29^{\mathrm{b}}$ \\
\hline \multirow{3}{*}{ Durum wheat } & Standard & $1.8^{\mathrm{c}}$ & $2.0^{c}$ & $2.0^{\mathrm{b}}$ & $1.2^{\mathrm{c}}$ & $14^{\mathrm{b}}$ & $16^{\mathrm{b}}$ & $23^{\mathrm{b}}$ & $61^{b}$ & $2.3^{\mathrm{b}}$ & $2.6^{\mathrm{b}}$ & $37^{\mathrm{b}}$ & $42^{\mathrm{b}}$ \\
\hline & Biosolids & $26^{\mathrm{a}}$ & $31^{\mathrm{a}}$ & $3.2^{\mathrm{a}}$ & $42^{\mathrm{a}}$ & $18^{\mathrm{a}}$ & $91^{\mathrm{a}}$ & $73^{\mathrm{a}}$ & $168^{\mathrm{a}}$ & $12^{\mathrm{a}}$ & $20^{\mathrm{a}}$ & $249^{\mathrm{a}}$ & $614^{\mathrm{a}}$ \\
\hline & Phosphate rock & $2.7^{\mathrm{b}}$ & $3.1^{\mathrm{b}}$ & $1.3^{\mathrm{c}}$ & $1.5^{\mathrm{b}}$ & $11^{\mathrm{c}}$ & $17^{\mathrm{b}}$ & $23^{\mathrm{b}}$ & $39^{c}$ & $3.0^{\mathrm{b}}$ & $3.2^{\mathrm{b}}$ & $36^{c}$ & $39^{b}$ \\
\hline
\end{tabular}

${ }^{\dagger}$ The differences of the metal concentrations among the treatments for each plant were tested by one-way ANOVA. In each column of each plant and among the treatments, values followed by same lowercase letter were not significantly different at $P<0.05$.

Dicots can acidify their rhizosphere more effectively when they fix nitrogen. Nitrogen enters the root as an uncharged molecule, and an excess of cations over anions can be absorbed by the root to balance the negative charge on newly formed proteins and organic acids, which are products of carbon and nitrogen assimilation. The excess cation uptake is balanced by a net $\mathrm{H}^{+}$efflux into the rhizosphere [40, 41]. Some organic acids (i.e., citric and malic) are well known for their capacity to desorb phosphate rock from sesquioxide surfaces by anion exchange [42]. Combinations of both desorption and chelation are responsible for phosphate rock mobilization. The capacity of organic acids in root exudates also depends on their concentration per unit volume of soil. Thus, it can be anticipated that with increasing density of root hairs or of lateral roots, the likelihood of organic acids mobilizing phosphate rock becomes higher $[5,43]$. In the previous paper [5], we reported that the composition of root-borne dicarboxylic organic acids (i.e., succinic, tartaric, and oxalic) varied between dicots and monocots and the total amount and production rate of organic acids from dicots were higher than those from monocots.

Data suggest the occurrence of interspecific variation in metal uptake (Table 5). For Cd, which is generally readily absorbed by plants, the average concentrations among the six species varied between 1.11-1.85, 13.9-29.4, and 1.38-4.87 $\mathrm{mg} \mathrm{kg}^{-1}$ for the sand medium without biosolids, biosolidstreated, and phosphate rock-treated medium, respectively (Table 5). The slightly higher Cd concentration in the shoots from phosphate rock treatment (versus nutrient solution) may be reflecting the presence of trace amounts of $\mathrm{Cd}$ in the phosphate rock. Plant absorption of $\mathrm{Cu}, \mathrm{Ni}, \mathrm{Pb}$, and $\mathrm{Zn}$ followed a similar trend. As in corn, $\mathrm{Cr}$ was not accumulated in the shoots, and the differences in tissue concentrations between the treatments were considerably smaller. For example, Cr concentrations in shoots were $0.86-1.96,1.31-4.61$, and $0.79-1.91 \mathrm{mg} \mathrm{kg}^{-1}$ for the sand medium without biosolids, biosolids-, and phosphate rock-treated medium, respectively. In the roots, as expected, $\mathrm{Cr}$ concentrations were 1.16-1.73, $16.8-77.1$, and $1.02-3.86 \mathrm{mg} \mathrm{kg}^{-1}$ for the sand medium without biosolids, biosolids treatments, and phosphate rock treatments, respectively. The trendy greater accumulation of metals in the roots is consistent with the general observation in the literature [29].

\section{Conclusions}

In this study, metal concentration in plant roots generally exceeded those in the shoots, irrespective of treatment. Exception was $\mathrm{Cd}$ in the shoots for the dicots. The amounts of metal transferred from the biosolids-treated medium to the plant varied with the metal element and followed the order: $\mathrm{Cd}>\mathrm{Ni}=\mathrm{Zn}>\mathrm{Cu}=\mathrm{Pb}>\mathrm{Cr}$. For corn grown on biosolidstreated medium, the amounts of metals removed by the plant were $14.2,9.8,8.6,1.6,1.4$, and $0.1 \%$ of the biosolids-borne metals in the rhizosphere, respectively, for the metals above. Interspecies and intercultivar differences in the metal uptake were trivial compared to intertreatment variations. Uptake rates for $\mathrm{Cd}$ and $\mathrm{Zn}$ by corn shoots remained constant for the first 8-10 weeks and tended to increase toward the end of the growth period. Among the metals examined, $\mathrm{Pb}$ and 
TABLE 6: P concentration of six plant species grown on sand media amended, without biosolids (Standard), with biosolids, and with phosphate rock ${ }^{\dagger}$.

\begin{tabular}{lccc}
\hline \multirow{2}{*}{ Plant } & Treatment & Shoot & Root \\
& Standard & $1,260^{\mathrm{c}}$ & $922.0^{\mathrm{c}}$ \\
Chickpea & Biosolids & $2,044^{\mathrm{b}}$ & $1,137^{\mathrm{b}}$ \\
& Phosphate rock & $2,580^{\mathrm{a}}$ & $1,513^{\mathrm{a}}$ \\
\hline \multirow{3}{*}{ Rape } & Standard & $1,743^{\mathrm{c}}$ & $1,564^{\mathrm{c}}$ \\
& Biosolids & $2,189^{\mathrm{b}}$ & $2,203^{\mathrm{b}}$ \\
\hline \multirow{2}{*}{ Swiss } & Phosphate rock & $3,354^{\mathrm{a}}$ & $2,707^{\mathrm{a}}$ \\
chard & Standard & $1,753^{\mathrm{c}}$ & $1,372^{\mathrm{c}}$ \\
& Biosolids & $2,141^{\mathrm{a}}$ & $3,261^{\mathrm{a}}$ \\
Corn & Phosphate rock & $2,029^{\mathrm{a}}$ & $2,631^{\mathrm{b}}$ \\
& Standard & $1,198^{\mathrm{a}}$ & $707.0^{\mathrm{b}}$ \\
\hline \multirow{2}{*}{ Sudan } & Biosolids & $1,192^{\mathrm{a}}$ & $763.0^{\mathrm{a}}$ \\
grass & Phosphate rock & $638.0^{\mathrm{b}}$ & $556.0^{\mathrm{c}}$ \\
\hline \multirow{2}{*}{ Durum } & Standard & $1,088^{\mathrm{b}}$ & $676.0^{\mathrm{b}}$ \\
wheat & Biosolids & $1,138^{\mathrm{a}}$ & $814.0^{\mathrm{a}}$ \\
& Phosphate rock & $756.0^{\mathrm{c}}$ & $553.0^{\mathrm{c}}$ \\
\hline
\end{tabular}

${ }^{\dagger}$ The differences of the P concentrations among the treatments for each plant were tested by one-way ANOVA. In each column of each plant and among treatments, values followed by same lowercase letter were not significantly different at $P<0.05$.

Cr apparently were only sparingly soluble from their biosolid source as indicated by their waning uptake as the growth period progressed.

\section{Acknowledgments}

The authors gratefully acknowledge Mr. D. Thomason, Mr. W. Smith, and Ms. N. J. Krage for technical assistance. This research was supported by the Water Environmental Research Foundation (WERF-97-REM-5) and California Baptist University's Trustees Distinguished Scholar Fund.

\section{References}

[1] G. Chiapusio, S. Pujol, M. L. Toussaint, P. M. Badot, and P. Binet, "Phenanthrene toxicity and dissipation in rhizosphere of grassland plants (Lolium perenne L. and Trifolium pratense L.) in three spiked soils," Plant and Soil, vol. 294, no. 1-2, pp. 103-112, 2007.

[2] G. Schilling, A. Gransee, A. Deubel, G. Ležovič, and S. Ruppel, "Phosphorus availability, root exudates, and microbial activity in the rhizosphere," Journal of Plant Nutrition and Soil Science, vol. 161, no. 4, pp. 465-478, 1998.

[3] I.-E. A. Ali, U. Kafkafi, I. Yamaguchi, Y. Sugimoto, and S. Inanaga, "Growth, transpiration, root-born cytokinins and gibberellins, and nutrient compositional changes in sesame exposed to low root-zone temperature under different ratios of nitrate: ammonium supply," Journal of Plant Nutrition, vol. 23, no. 1, pp. 123-140, 2000.

[4] A. B. Pomilio, S. R. Leicach, M. Y. Grass, C. M. Ghersa, M. Santoro, and A. A. Vitale, "Constituents of the root exudates of Avena fatua grown under far-Infrared-enriched light," Phytochemical Analysis, vol. 11, pp. 304-308, 2000.

[5] B.-J. Koo, A. C. Chang, D. E. Crowley, and A. L. Page, "Characterization of organic acids recovered from rhizosphere of corn grown on biosolids-treated medium," Communications in Soil Science and Plant Analysis, vol. 37, no. 5-6, pp. 871-887, 2006.

[6] L. Ruta, C. Paraschivescu, M. Matache, S. Avramescu, and I. C. Farcasanu, "Removing heavy metals from synthetic effluents using "kamikaze" Saccharomyces cerevisiae cells," Applied Microbiology and Biotechnology, vol. 85, no. 3, pp. 763-771, 2010.

[7] C. Engels and H. Marschner, "Influence of the form of nitrogen supply on root uptake and translocation of cations in the xylem exudate of maize (Zea mays L.)," Journal of Experimental Botany, vol. 44, no. 268, pp. 1695-1701, 1993.

[8] S. Nardi, F. Reniero, and G. Concheri, "Soil organic matter mobilization by root exudates of three maize hybrids," Chemosphere, vol. 35, no. 10, pp. 2237-2244, 1997.

[9] C. C. Young, C. H. Chang, L. F. Chen, and C. C. Chao, "Characterization of the nitrogen fixation and ferric phosphate solubilizing bacteria isolated from a Taiwan soil," Journal of the Chinese Agricultural Chemical Society, vol. 35, pp. 201-210, 1998.

[10] A. A. Pohlman and J. G. McColl, "Kinetics of metal dissolution from forest soils by soluble organic acids," Journal of Environmental Quality, vol. 15, no. 1, pp. 86-92, 1986.

[11] D. L. Jones and L. V. Kochian, "Aluminium-organic acid interactions in acid soils: I. Effect of root-derived organic acids on the kinetics of Al dissolution," Plant and Soil, vol. 182, no. 2, pp. 221228, 1996.

[12] F. Awad and V. Römheld, "Mobilization of heavy metals from contaminated calcareous soils by plant born, microbial and synthetic chelators and their uptake by wheat plants," Journal of Plant Nutrition, vol. 23, no. 11-12, pp. 1847-1855, 2000.

[13] H. Marschner, V. Romheld, and M. Kissel, "Different strategies in higher plants in mobilization and uptake of iron," Journal of Plant Nutrition, vol. 9, pp. 695-713, 1986.

[14] S. A. Wasay, S. F. Barrington, and S. Tokunaga, "Remediation of soils polluted by heavy metals using salts of organic acids and chelating agents," Environmental Technology, vol. 19, no. 4, pp. 369-379, 1998.

[15] A. H. M. Veeken and H. V. M. Hamelers, "Removal of heavy metals from sewage sludge by extraction with organic acids," Water Science and Technology, vol. 40, no. 1, pp. 129-136, 1999.

[16] D. J. Linehan, A. H. Sinclair, and M. C. Mitchell, "Seasonal changes in $\mathrm{Cu}, \mathrm{Mn}, \mathrm{Zn}$ and Co concentrations in soil in the root-zone of barley (Hordeum vulgare L.)," Journal of Soil Science, vol. 40, pp. 103-115, 1989.

[17] J. L. Morel, F. Andreux, L. Habib, and A. Guckert, "Comparison of the adsorption of maize root mucilage and polygalacturonic acid on montmorillonite homoionic to divalent lead and cadmium," Biology and Fertility of Soils, vol. 5, no. 1, pp. 13-17, 1987.

[18] M. Mench, J. L. Morel, and A. Guckert, "Metal binding properties of high molecular weight soluble exudates from maize (Zea mays L.) roots," Biology and Fertility of Soils, vol. 3, no. 3, pp. 165-169, 1987.

[19] M. Mench, J.-L. Morel, and A. Guckert, "Influence of metal [Cd(II), $\mathrm{Cu}(\mathrm{II}), \mathrm{Pb}(\mathrm{II}), \mathrm{Zn}(\mathrm{II})]$ ion supply on soluble root exudation from maize (Zea mays L.)," Agronomie, vol. 8, no. 3, pp. 237-241, 1988. 
[20] F. M. Eaton, "Automatically operated sand-culture equipment," Journal of Agricultural Research, vol. 53, pp. 433-444, 1936.

[21] M. Mench and E. Martin, "Mobilization of cadmium and other metals from two soils by root exudates of Zea mays L., Nicotiana tabacum L. and Nicotiana rustica L," Plant and Soil, vol. 132, no. 2, pp. 187-196, 1991.

[22] G. S. R. Krishnamurti, G. Cieslinski, P. M. Huang, and K. C. J. Van Rees, "Kinetics of cadmium release from soils as influenced by organic acids: implication in cadmium availability," Journal of Environmental Quality, vol. 26, no. 1, pp. 271-277, 1997.

[23] L. E. Sommers, A. L. Page, T. J. Logan, and J. A. Ryan, Impact of Sewage Sludge on Soils and Barley: A Regional Study, Western Regional Research Publication W-124, Optimum Use of Sewage Sludge on Agricultural Land, Agricultural Experiment Station, Colorado State University, Ft. Collins, Colo, USA, 1991.

[24] D. R. Hoagland and D. I. Arnon, The Water-Culture Method for Growing Plants Without Soil, University of California Agricultural Experiment Station Circular 347, Berkley, Calif, USA, 1950.

[25] J.-G. Kang and M. W. Van Iersel, "Nutrient solution concentration affects growth of subirrigated bedding plants," Journal of Plant Nutrition, vol. 25, no. 2, pp. 387-403, 2002.

[26] C. G. Millward and P. D. Kluckner, "Microwave digestion technique for the extraction of minerals from environmental marine sediments for analysis by inductively coupled plasma atomic emission spectrometry and atomic absorption spectrometry," Journal of Analytical Atomic Spectrometry, vol. 4, no. 8, pp. 709$713,1989$.

[27] J. L. Morel, M. Mench, and A. Guckert, "Measurement of $\mathrm{Pb}^{2+}$, $\mathrm{Cu}^{2+}$ and $\mathrm{Cd}^{2+}$ binding with mucilage exudates from maize (Zea mays L.) roots," Biology and Fertility of Soils, vol. 2, no. 1, pp. 2934, 1986.

[28] N. E. Nielsen, "The effect of plants on the copper concentration in the soil solution," Plant and Soil, vol. 45, no. 3, pp. 679-687, 1976.

[29] D. C. Adriano, Trace Elements in Terrestrial Environments: Biogeochemistry, Bioavailability, and Risks of Metals, Springer, New York, NY, USA, 2nd edition, 2001.

[30] A. C. Chang, J. E. Warneke, A. L. Page, and L. J. Lund, "Accumulation of heavy metals in sewage sludge-treated soils," Journal of Environmental Quality, vol. 13, no. 1, pp. 87-91, 1984.

[31] P. S. Hooda and B. J. Alloway, "Effects of time and temperature on the bioavailability of $\mathrm{Cd}$ and $\mathrm{Pb}$ from sludge-amended soils," Journal of Soil Science, vol. 44, pp. 97-110, 1993.

[32] B. R. James and R. J. Bartlett, "Behavior of chromium in soils: VII. Adsorption and reduction of hexavalent forms," Journal of Environmental Quality, vol. 12, no. 2, pp. 177-181, 1983.

[33] R. J. Bartlett and J. M. Kimble, "Behavior of chromium in soils: II. Hexavalent forms," Journal of Environmental Quality, vol. 5, no. 4, pp. 383-386, 1976.

[34] E. E. Cary, W. H. Allaway, and O. E. Olson, "Control of chromium concentrations in food plants. 2. Chemistry of chromium in soils and its availability to plants," Journal of Agricultural and Food Chemistry, vol. 25, no. 2, pp. 305-309, 1977.

[35] N. S. Bolan, D. C. Adriano, R. Natesan, and B.-J. Koo, "Effects of organic amendments on the reduction and phytoavailability of chromate in mineral soil," Journal of Environmental Quality, vol. 32, no. 1, pp. 120-128, 2003.

[36] F. T. Bingham, A. L. Page, R. J. Mahler, and T. J. Ganje, "Cadmium availability to rice in sludge amended soil under "Flood" and "Nonflood" culture," Soil Science Society of America Journal, vol. 40, no. 5, pp. 715-719, 1976.
[37] Y. K. Soon, T. E. Bates, and J. R. Moyer, "Land application of chemically treated sewage sludge: III. Effects on soil and plant heavy metal content," Journal of Environmental Quality, vol. 9, no. 3, pp. 497-504, 1980.

[38] A. C. Chang, A. L. Page, and J. E. Warneke, "Long-term sludge applications on cadmium and zinc accumulation in Swiss chard and radish," Journal of Environmental Quality, vol. 16, no. 3, pp. 217-221, 1987.

[39] P. E. H. Gregg, A. D. Mackay, L. D. Currie, and J. K. Syers, "Application strategies for Sechura phosphate rock use on permanent pasture," Fertilizer Research, vol. 17, no. 3, pp. 219-234, 1988.

[40] T. Nyatsanga and W. H. Pierre, "Effect of nitrogen fixation by legumes on soil acidity," Agronomy Journal, vol. 65, pp. 936-940, 1973.

[41] N. S. Bolan, M. J. Hedley, and R. E. White, "Nitrogen fertilizer use: fixation and soil acidification," in Nitrogen in New Zealand Agriculture and Horticulture, R. E. White and L. D. Currie, Eds., Occasional Report no. 3, pp. 88-103, Fertilizer and Lime Research Centre, Massey University, Palmerston North, New Zealand, 1989.

[42] R. L. Parfitt, "The availability of P from phosphate-goethite bridging complexes. Desorption and uptake by ryegrass," Plant and Soil, vol. 53, no. 1-2, pp. 55-65, 1979.

[43] W. K. Gardner, D. G. Parbery, D. A. Barber, and L. Swinden, "The acquisition of phosphorus by Lupinus albus L.: V. The diffusion of exudates away from roots: a computer simulation," Plant and Soil, vol. 72, no. 1, pp. 13-29, 1983. 

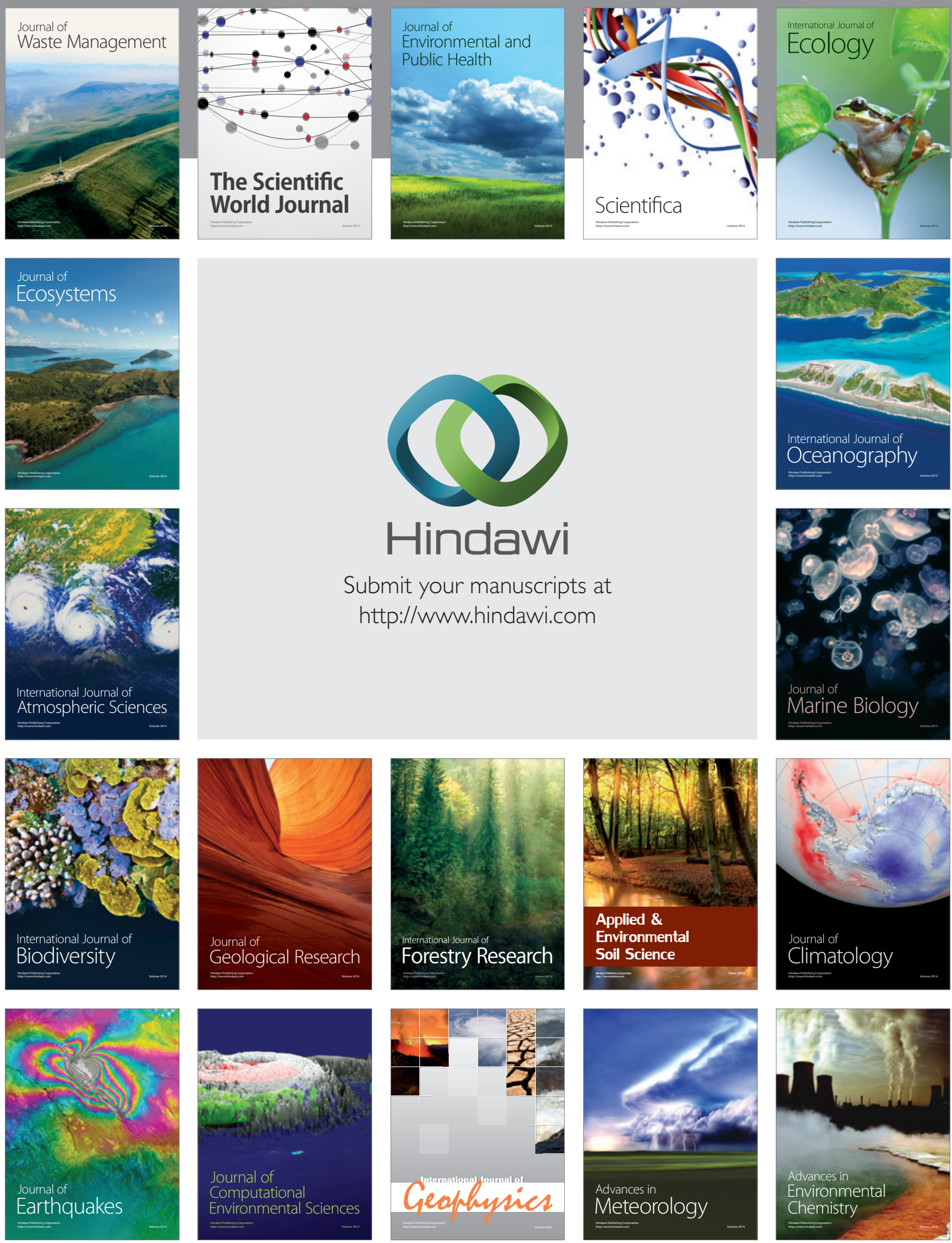